\title{
Першочергові завдання плану дій щодо зменшення рівнів радону в повітрі будинків
}

- Павленко Тетяна Олександрівна, д-р. біол. наук, проф.

Державна установа «Інститут громадського здоров'я ім. О. М. Марзєєва

Національної академії медичних наук України», м. Київ, Україна

ORCID: https://orcid.org/0000-0003-0615-3123

- Оперчук Анатолій Павлович

Державна установа «Центр громадського здоров'я

Міністерства охорони здоров'я України», м. Київ, Україна

ORCID: https://orcid.org/0000-0002-0944-8683

- Аксьонов Микола Васильович, канд. біол. наук

Державна установа «Інститут громадського здоров'я ім. О. М. Марзєєва Національної академії медичних наук України», м. Київ, Україна

ORCID: https://orcid.org/0000-0002-5643-6378

- Фризюк Мирослава Анатоліївна, канд. біол. наук

Державна установа «Інститут громадського здоров'я ім. О. М. Марзєєва Національної академії медичних наук України», м. Київ, Україна

ORCID: https://orcid.org/0000-0003-0764-010X

\section{- Михайленко Олександр Васильович}

Державна установа «Інститут громадського здоров'я ім. О. М. Марзєєва Національної академії медичних наук України», м. Київ, Україна

ORCID: https://orcid.org/0000-0002-4395-3413

- Горваль Алла Костянтинівна, канд. мед. наук

Державна установа «Інститут громадського здоров'я ім. О. М. Марзєєва Національної академії медичних наук України», м. Київ, Україна

ORCID: https://orcid.org/0000-0002-2696-2916

У статті надано обгрунтування першочергових завдань першого етапу плану дій щодо радону в Україні.

У першій частині статті була проаналізована інформація щодо середньогеометричних значень активності радону в повітрі будинків на рівні районів окремих областей України. Показано, що наявних даних недостатньо для висновків стосовно радононебезпечності майже половини території країни. Тому важливим завданням $\epsilon$ продовження досліджень рівнів радону в повітрі будівель на ще не обстежених територіях. Для таких досліджень необхідно розробити єдині протоколи вимірювань і відповідну систему гарантій якості, в якій міжлабораторні порівняння мають стати усталеною практикою щодо перевірки достовірності результатів вимірювань. Це стане основою запровадження державних баз даних та можливості реалізації єдиного інформаційного простору щодо радіаційних ризиків.

У статті міститься порівняльний аналіз існуючої в Україні нормативної бази щодо радіаційного захисту населення з міжнародними стандартами. Встановлено, що чинна нормативна база має бути переглянута та вдосконалена. Регуляторні органи повинні визначитись не тільки з величиною нормативу, а й перейти до нової одиниці - об'ємної активності радону (концентрації радону або газу радону), запровадити нормативи для робочих місць, які сьогодні взагалі відсутні. 
У завершальній частині статті обґрунтовано необхідність запровадження системи підготовки фахівців 3 питань захисту від радону та розробки стратегії комунікацій зі всіма потенційними учасниками реалізації плану дій (органами державної влади, міністерствами, регулюючими органами, бізнесом, засобами масової інформації, громадськими організаціями, населенням тощо).

Визначено, що для реалізації державного плану дій необхідно розробити рекомендації для організації та затвердження регіональних програм, серед яких $€$ методичні рекомендації, які містять основні напрями і завдання залежно від ступеня радононебезпечності певної території.

Ключові слова: радон у повітрі будівель, план дій щодо радону, референтний рівень, інформування про ризики.

( С Павленко Т. О., Оперчук А. П., Аксьонов М. В., Фризюк М. А., Михайленко О. В., Горваль А. К., 2021

\section{Вступ}

Тема обмеження опромінення населення радоном вельми актуальна в усьому світі і досить давно обговорюється українськими провідними фахівцями, зокрема і за участю авторів цієї статті [1]-[3]. У листопаді 2019 року Кабінет Міністрів України нарешті затвердив національний план дій щодо радону [4], який за своєю змістовною частиною повністю відповідає вимогам Основних стандартів безпеки (BSS) Міжнародного агентства 3 атомної енергії (МАГАТЕ) і Європейського співтовариства з атомної енергії (Євратом) [5]-[7].

Підготовка та розробка основних положень цього плану дій містила попередній аналіз ситуації в Україні щодо радононебезпечності житлового фонду, аналіз наявної нормативної бази та ресурсів щодо радіаційного захисту, визначення першочергових завдань тощо.

Проте для успішної реалізації плану дій уряд має вирішити низку організаційних питань, а саме: створити координаційну раду з усіх зацікавлених відомств, організацій та установ і забезпечити фінансування основних напрямів робіт; визначити компетенції міністерств та відомств, відповідальних за контроль реалізації заходів у громадських спорудах та будинках, контроль за роботодавцями щодо дотримання референтних рівнів активності радону на робочих місцях; визначити головну організацію з реалізації плану дій. Обов'язками головної організації має бути координація та реалізація державної політики 3 питань зменшення радіаційних ризиків від опромінення радоном, комунікація 3 усіма установами-учасниками за окремими напрямами плану дій, забезпечення інформування державних органів влади і населення про величину встановлених радіаційних ризиків від радону та надання інформації населенню про шляхи їх зменшення.

Вирішення цих організаційних питань $є$ запорукою успішної реалізації плану дій щодо радону.
Метою цієї статті $\epsilon$ аналіз існуючих проблем щодо захисту населення від радону та обґрунтування першочергових завдань першого етапу плану заходів, які забезпечать його успішну практичну реалізацію.

\section{Матеріали та методи дослідження}

Вимірювання рівнів радону в повітрі приміщень були проведені методом пасивної трекової радонометрії з експозицією не менше 30 діб в опалювальний сезон. Гарантії якості вимірювань радону забезпечувалися калібруванням детекторів у радоновій атмосфері з відомою об'ємною активністю (OA), яка має в системі Держстандарту України статус робочого еталону одиниці ОА ${ }^{222} \mathrm{Rn}$. Результати вимірювань підтверджено процедурами порівняння зі Шведським управлінням з радіаційної безпеки (Swedish Radiation Safety Authority (Strål säkerhets myndigheten - SSM)) та Національним інститутом радіологічних наук Японіï (National Institute of Radiological Science).

Для визначення радіаційних ризиків та економічних збитків від опромінення людини радоном у повітрі приміщень використовувались дозові коефіцієнти, методи та математичні моделі Міжнародної комісії з радіаційного захисту (МКРЗ) за публікаціями 55 [8], 126 [9], 137 [10], та бази даних лабораторії радіаційного захисту Державної установи «нститут громадського здоров'я ім. О. М. Марзєєва Національної академії медичних наук України»» щодо активностей радону в повітрі будинків.

\section{Результати дослідження та їх обговорення}

На першому етапі реалізації плану дій у рамках академічної науково-дослідної роботи «Наукове обґрунтування та розробка основних положень Державного плану дій щодо захисту населення України від радону в контексті імплементації 
Директиви ради 2013/59/ЄВРАТОМ» (№ держреєстрації 0119U101022) [11] була проаналізована наявна інформація щодо активностей радону в повітрі будинків різних регіонів України, накопичену за результатами вимірювань з початку 1990-х років і до тепер, та відповідність нормативно-правової бази України вимогам міжнародних стандартів з радіаційної безпеки.

На Рисунку 1 наведено узагальнені дані щодо середньогеометричних значень ОА радону в повітрі будинків на рівні районів окремих областей. У контексті мети цієї статті, результати цього дослідження - це повна відсутність будь-якої інформації про радононебезпечність житла в майже половині районів України (білий колір на карті). Тому дослідження вмісту радону в повітрі будівель мають бути продовжені на ще не обстежених територіях. Отже, на першому етапі було 6 доречно розробити положення та структуру регіональних програм і визначитись з правилами організації та проведення вимірювань рівнів радону.

Водночас, для проведення вимірювань необхідно мати не тільки прилади та методики, а й відповідну систему гарантій якості, затверджені алгоритми визначення радононебезпечності будинків, протоколи проведення протирадонових заходів та оцінки їх ефективності тощо.
Система гарантій якості вимірювань. 31 січня 2016 року відповідно до Закону України «Про метрологію та метрологічну діяльність» [12] проведення атестації вимірювальних лабораторій у державній метрологічній системі не передбачено. Внаслідок цього вимірювальні лабораторії повинні самі дбати про якісний сервіс вимірювань. Для підтвердження своєї компетентності вимірювальні лабораторії можуть звертатися до державних центрів стандартизації або інших організацій щодо калібрування та порівняння результатів вимірювання.

Одним з прийнятих в Україні та на міжнародному рівні методом підтвердження компетентності $\epsilon$ відповідність вимірювальних лабораторій вимогам ДСТУ ISO/IEC 17025:2017 [13]. Цей стандарт установлює, зокрема, вимоги щодо забезпечення та перевірки кваліфікації і компетентності працівників, наприклад, через участь лабораторії в міжлабораторних порівняннях. Порівняння - це усталена світова практика з перевірки достовірності вимірювань радіоактивності, включно 3 радоном, тому що саме порівняння та єдині протоколи вимірювань $\epsilon$ основою запровадження державних баз даних, можливості реалізації єдиного інформаційного простору щодо радіаційних ризиків, систем аналізу даних для оцінки ефективності реалізації плану дій та підтримки ухвалення подальших рішень регулюючих органів.

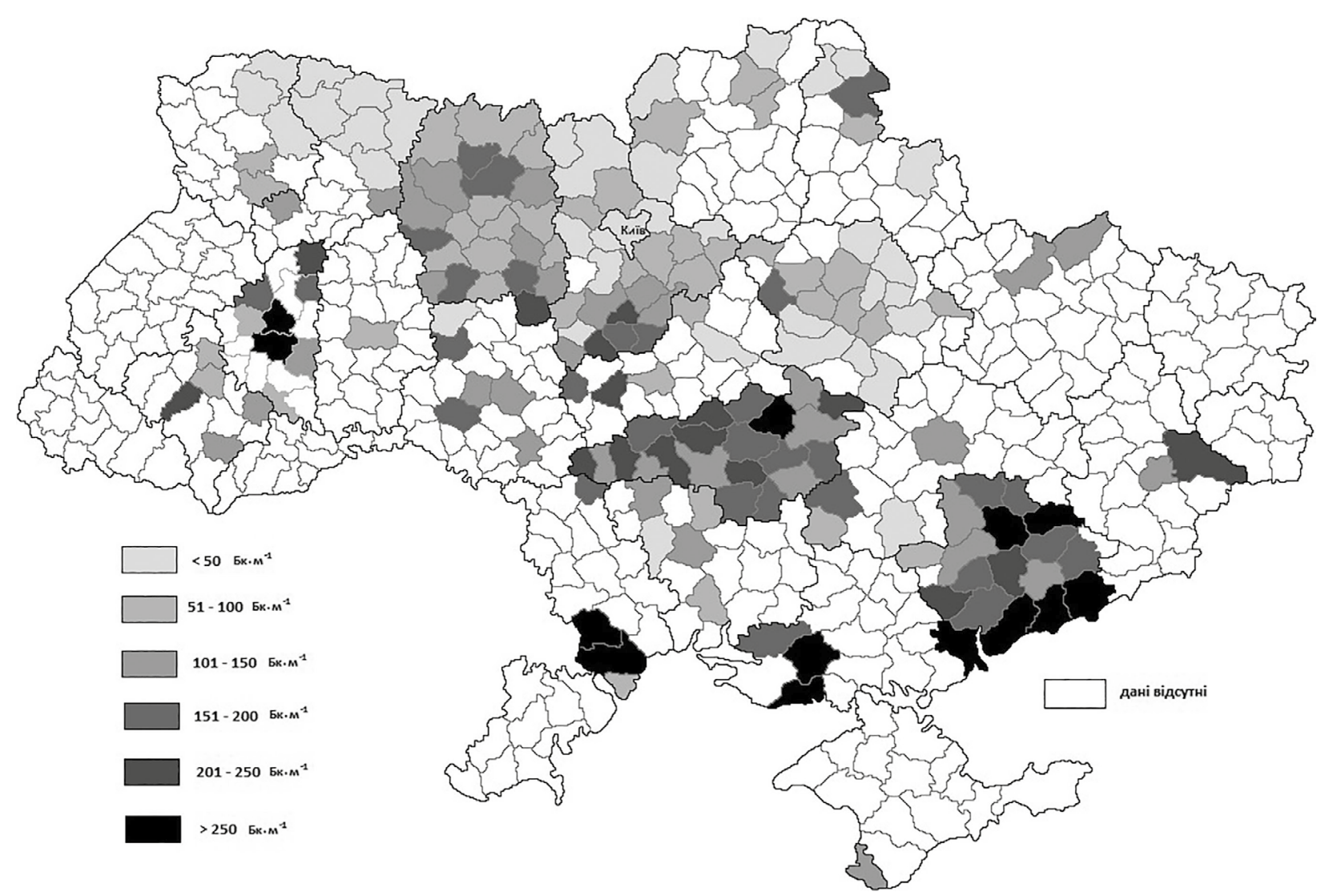

Рисунок 1 - Середньозважені значення активностей радону в повітрі односімейних будинків на території України 
Система гарантій якості вимірювань і порівняння щодо радону має багаторічний досвід у багатьох країнах світу. Втім існують певні розбіжності в програмах перевірки кваліфікації та їх змісті, але це обов'язкова і невід'ємна частина радонового сервісу в усіх країнах [14]-[16].

Тому на першому етапі плану дій для забезпечення гарантії якості вимірювань радону в будівлях необхідно розробити єдині вимоги до перевірки компетентності лабораторій (зокрема проведення міжлабораторних порівнянь).

Методи вимірювання. Не менш важливою умовою отримання коректного результату $\epsilon$ застосування адекватних методів вимірювання рівнів радону. На українському ринку сьогодні існує майже два десятки приладів, які вимірюють радон або його дочірні продукти розпаду (ДПР). Проте, в «Нормах радіаційної безпеки (НРБУ-97)» [17] установлено певні вимоги до часу експозиції радонометрів під час контролю нормативу. Так, активність радону в повітрі приміщень має вимірюватися тільки інтегральними методами, які дозволяють усереднювати варіабельність активності за певний проміжок часу. Інтегральні методи вимірювань радону сьогодні використовуються в понад 98 \% країн Європи, причому на трекові методи приходиться майже 80 \%, на вимірювання електретами - 11,6 \% [16]. Встановлений у протоколах вимірювань різних країн час експозиції радонометрів у будинках варіюється від 30 діб до півроку [14].

Радонометри, які вимірюють миттєві значення, використовуються для пошуку джерела надходження радону в приміщення або визначення його активності в повітрі грунту. Зрештою, кожен метод вимірювання має своє призначення.

Практика контролю радону в Україні показала, що дуже часто вимірювальні лабораторії застосовують активні прилади для миттєвих вимірювань активності радону в повітрі будинків, порушуючи вимоги НРБУ [17]. Саме тому вкрай необхідно запроваджувати протоколи проведення досліджень - алгоритми дій на всіх стадіях реалізації протирадонових заходів: вимірювання активностей радону з метою контролю відповідності референтним значенням, протокол пошуку джерела надходження, а також визначення активностей радону в ґрунтовому повітрі як параметра розрахунків вентиляційних систем, заходів з відведення потоків радону з-під будинку чи оптимальних заходів щодо герметизації внутрішнього простору будівель і, нарешті, контролю ефективності протирадонових заходів.

Отже, розроблення та затвердження процедурних протоколів $є$ однією з першочергових задач, без вирішення якої реалізація плану дій не можлива.

Регламенти. На першому етапі досліджень був проведений порівняльний аналіз існуючої в Україні нормативної бази 3 міжнародни- ми стандартами 3 радіаційного захисту. Визначено, що для радону в повітрі приміщень міжнародні стандарти впровадили нову величину «референтний рівень», який виражений В одиницях ОА радону (в англійському варіанті - концентрації радону або газу радону). По суті «референтний рівень» - це верхній ліміт, перевищувати який заборонено [9], [18]. Нормативи мають бути меншими за 300 Бк/м², проте рішення про величину їхнього кількісного значення кожна країна вирішує самостійно, залежно від соціальних та економічних умов, ставлення громадськості до радіаційних ризиків тощо.

На сьогодні в НРБУ-97 для контролю радону застосовується еквівалентна рівноважна об'ємна активність (ЕРОА) радону [17], а рівень дій (норматив)

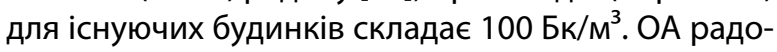
ну відрізняється від його ЕРОА величиною коефіці$\epsilon$ та рівноваги, тобто співвідношенням між активностями радону та його ДПР [17]. У більшості лабораторій світу вимірюють саме ОА радону, а потім застосовують рекомендований МКРЗ коефіцієнт рівноваги 0,4 [9] і перераховують виміряні величини в ЕРОА. Така усталена практика радіаційного контролю радону призвела до визнання необхідності спрощення цієї процедури, і за референтний рівень щодо активності було обрано саме ОА радону, тобто величину, яку простіше вимірювати.

Якщо перерахувати ЕРОА радону в активність «радону газу» чи в його ОА, величина чинного в

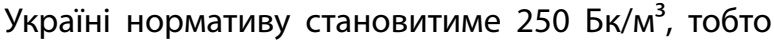
ця величина не перевищує референтні рівні BSS і Євратома (300 Бк/м³) [9]. Існує два варіанти подальших дій: перший - залишити існуючі нормативні значення; другий - затвердити рекомендований референтний рівень ОА радону $300 \mathrm{5k} / \mathrm{m}^{3}$. Але яка вартість цієї різниці для економіки країни?

Аналіз наявних результатів вимірювань установив, що рівень у $250 \mathrm{5 \kappa} / \mathrm{m}^{3}$ перевищується у $21 \%$ випадків, а рекомендований МАГАТЕ референтний рівень $300 \mathrm{БK} / \mathrm{m}^{3}$ - у $16 \%$, тобто різниця складає приблизно 5 \% житлового фонду країни. Якщо оцінити відповідні радіаційні ризики за прийнятими у світовій практиці методами їх оцінки та дозовими коефіцієнтами публікації 137 МКР3 [10], кількість смертей від раку легенів, зумовлених радоном, буде становити близько 440 випадків на рік [8], [10]. У грошовому еквіваленті відповідні прямі збитки для економіки країни сьогодні складають близько 22,5 мільйонів доларів щорічно за демографічними показниками 2019 року [19]. Інші, непрямі складові збитків, а саме: моральні, соціальні, психологічні наслідки опромінення, можуть бути набагато більші. Розмір цієї компоненти може перевищувати прямі збитки в десятки разів [20]. Так, діапазон «вартості життя» чи «вартості ризику» для різних країн світу варіюється від 2 тисяч до 5 мільйонів доларів США [21]. 
Якщо враховувати, що відповідні оцінки вартості життя в Україні складають від 6 тисяч до 100 тисяч доларів [20], збитки за рік можуть бути значно більші - до 200 мільйонів доларів.

Отже, сьогодні необхідно визначитись не тільки 3 величиною нормативу, а і перейти до нової одиниці - ОА радону, запровадити норматив для робочих місць, який зараз взагалі відсутній, тощо. Безперечно, чинна нормативна база з радіаційного захисту має бути переглянута та вдосконалена.

Наступні, не менш важливі завдання першого етапу плану дій, - це підготовка фахівців та розробка стратегії комунікацій із стейкхолдерами. Саме поняття «стейкхолдер» - відносно нове у вітчизняній практиці радіаційного захисту і, власне, не має аналогів в українській термінології. Близьким за змістом є термін «зацікавлені сторони», але він вже має юридичне визначення в законодавстві, яке по суті не співпадає з поняттям «стейкхолдер» у радіаційному захисті. Безперечно, термінологічні колізії мають бути вирішені під час розробки нових норм радіаційної безпеки і стосуватися не тільки цього поняття. По суті, «стейкхолдери» - це всі потенційні учасники реалізації плану дій, починаючи з органів державної влади, міністерств, регулюючих органів, бізнесу і закінчуючи засобами масової інформації, громадськими організаціями та населенням.

На першому етапі конче необхідно запровадити програмипідготовки фахівців, якібудуть працювати за планом дій на місцях. Такі курси-тренінги, які за невеликий проміжок часу дозволяють підготувати фахівців з питань захисту від радону, були розроблені та впроваджені за досвідом SSM у рамках міжнародного проєкту UA601A «Reduction of risks caused by exposure to radon gas and natural radiation» (2009 - 2012) [22]. Ці курси були успішно випробувані в рамках пілотного проєкту «Стоп радон» на Кіровоградщині [22]. На першому етапі цього проєкту для фахівців державних служб були проведені курси-тренінги «Радон - базовий», «Радон - вимірювання», «Картування радонових потенціалів», «Протирадонові заходи». Надалі ця команда очолила та успішно реалізовувала перші етапи програми, яку, на жаль, сьогодні призупинено. Проте за 4 роки було обстежено всі дитячі заклади та школи області, у 189 школах проведено протирадонові заходи та оцінено їх ефективність, розроблено та реалізовано на практиці освітні програми для школярів і населення тощо [22]. Як результат - радіаційні ризики для дітей Кіровоградщини було знижено вдвічі, зменшено в громаді соціальну напругу, пов'язану не тільки 3 радононебезпечністю цієї території, а й з впливом розташованих на території області уранових шахт [22].

Практика довела, що такий підхід до організації регіональних блоків плану дій $\epsilon$ дієвим інструментом щодо їхньої успішної реалізації.

\section{Висновки}

1. Установлено, що для половини території України відсутня інформація про рівні радону в повітрі будинків, тому необхідно продовжити дослідження активності радону в повітрі будівель на ще не обстежених територіях.

2. Установлено, що дослідження рівнів радону потребує розробки єдиних протоколів вимірювань і відповідної системи гарантій якості, яка міститиме обов'язкові міжлабораторні порівняння.

3. Визначено, що чинна нормативно-правова база України щодо радону потребує перегляду та вдосконалення відповідно до вимог міжнародних стандартів безпеки. Необхідно визначитись не тільки з величиною нормативу, а і перейти до нової одиниці - ОА радону (концентрації радону або газу радону), запровадити норматив для робочих місць.

4. Визначено, що необхідно починати готувати фахівців з питань захисту від радону та розробити стратегію комунікацій із усіма потенційними учасниками реалізації плану дій.

\section{Список використаної літератури}

1. Аксьонов М. В., Фризюк М. А., Тарасюк О. $\epsilon$. Концептуальні засади створення плану дій щодо захисту населення від радону (огляд міжнародних вимог). Гігієна населених місць : зб. наук. пращь. 2018. № 68. С. 171-177.

2. Павленко Т. О. Радіаційний захист населення: вимоги до обмеження опромінення природними джерелами. Гігієна населених місць : зб. наук. праць. 2018. № 68. С. 167-171.

3. Аксьонов М. В., Фризюк М. А., Павленко Т. О. Світовий досвід запровадження планів дій щодо захисту від радону (огляд). Гігієна населених місць : зб. наук. праць. 2019. № 69. С. 154-164.

4. Розпорядження Кабінету Міністрів України від 27.11.2019 № 1417-р «Про затвердження плану заходів щодо зниження рівня опромінення населення радоном та продуктами його розпаду, мінімізації довгострокових ризиків від поширення радону в житлових та нежитлових будівлях, на робочих місцях на 2020-2024 роки». URL: https://zakon.rada.gov.ua/laws/show/1417-2019p\#Text.

5. Radiation Protection and Safety of Radiation Sources: International Basic Safety Standards. IAEA General Safety Requirements No. GSR Part 3. Vienna : IAEA, 2014. 436 p.

6. Protection of the Public against Exposure Indoors due to Radon and Other Natural Sources of Radiation. IAEA Specific Safety Guide No. SSG-32. Vienna : IAEA, 2015. 90 p.

7. Council Directive 2013/59/Euratom of 5 December 2013 Laying Down Basic Safety Standards for Protection against the Dangers Arising from Exposure to Ionising Radiation, and Repealing Directives 89/618/Euratom, 90/641/Euratom, 
96/29/Euratom, 97/43/Euratom and 2003/122/Euratom. Official Journal of the European Union. 2014. Vol. 57, L13. P. 1-73.

8. ICRP Publication 55. Optimization and Decision-making in Radiological Protection. Annals of the ICRP. 1988. Vol. 20 (1). 60 p.

9. ICRP Publication 126. Radiological Protection against Radon Expozure. Annals of the ICRP. 2014. Vol. 43 (3). 73 p.

10. ICRP Publication 137. Part 3. Occupational Intakes of Radionuclides. Annals of the ICRP. 2017. Vol. 46 (3-4). 486 p.

11. Наукове обґрунтування та розробка основних положень Державного плану дій щодо захисту населення України від радону в контексті імплементації Директиви ради 2013/59/ЄВРАТОМ : звіт про НДР (проміжний). ДУ «Інститут громадського здоров'я ім. О. М. Марзеєва НАМН України» (ДУ «ІГЗ НАМНУ»). Керівник Т. О. Павленко. № ДР $0119 U 101022$. К., 2019. 85 c.

12. Про метрологію та метрологічну діяльність: Закон України від 05.06.2014 р. № 1314-VII (із змінами) станом на 03.07.2020 № 1314-VII, підстава № 2740-VIII. URL : https://zakon.rada.gov.ua/laws/show/1314-18\#Text.

13. Новіков В.М. Авторський переклад міжнародного стандарту ISO/IEC 17025:2017 «General requirements for the competence of testing and calibration laboratories» (Загальні вимоги до компетентності випробувальних та калібрувальних лабораторій: ДСТУ ISO/IEC 17025:2017). K., 2017.40 c.

14. Friedmann $\mathrm{H}$. Final results of the Austrian radon project. Health Phys. 2005. Vol. 89. P. 339-348. doi: 10.1097/01. HP.0000167228.18113.27.

15. Howarth C. B., Miles J. C. H. Results of the 2003 NRPB Intercomparison of Passive Radon Detectors. HPA-RPD-027. 2007. 63 p. URL : https://assets.publishing.service.gov.uk/ government/uploads/system/uploads/attachment_data/ file/340119/HpaRpd027.pdf.

16. Pantelić G., Čeliković I., Živanović M., Vukanac I., Nikolić J. K., Cinelli G., Gruber V. Qualitative overview of indoor radon surveys in Europe. Journal of Environmental Radioactivity. 2019. Vol. 204. P. 163-174. doi: 10.1016/j.jenvrad.2019.04.010.

17. Норми радіаційної безпеки України (НРБУ-97): Державні гігієнічні нормативи. ДГН 6.6.1.-6.5.001-98. K., 1998. 135 C.

18. ICRP Publication 115. Lung Cancer Risk from Radon and Progeny and Statement on Radon. Annals of the ICRP. 2010. Vol. 40 (1). P. 1-64.

19. Населення України. Чисельність населення України в 2019 p. MIHФIH. URL : https://index.minfin.com.ua/ua/ reference/people/2019/.

20. Горбулін В. П., Качинський А. Б. Системноконцептуальні засади стратегії національної безпеки України. К. : Євроатлантикінформ, 2007. 540 с.

21. Семейство баз данных ЕРБ ВОЗ «Здоровье для всех». Всемирная организация здравоохранения. Европейское региональное бюро. URL: http://www.euro.who.int/ru/whatwe-do/data-and-evidence/databases/european-health-for-alldatabase-hfa-db2.

22. Pavlenko T., German O., Frizyuk M., Aksenov N., Operchyuk A. The Ukrainian pilot project «Stop Radon». Nuclear Technology \& Radiation Protection. 2014. Vol. 29 (2). P. 42-148. doi: 10.2298/NTRP1402142P.
23. Pavlenko T., German O., Aksenov N., Fryzyuk M., Operchuk A. Radon remediation efficiency assessment in Kirovograd region, Ukraine. Nuclear Technology and Radiation Protection. 2018. Vol. 33. No. 3. P. 317-323. doi: 10.2298/ NTRP1803317P.

\section{References}

1. Aksenov, N., Fryziuk, M., Tarasiuk, O. (2018). Conceptual basics of action plan creation to protect population from radon (review of international requirements). Hygiene of Populated Places: Scientific Journal, No. 68, 171-177.

2. Pavlenko, T. (2018). Radiation protection of public: requirements for limition of natural radiactivity resources. Hygiene of Populated Places: Scientific Journal, No. 68, 167-171.

3. Aksenov, N., Fryziuk, M., Pavlenko, T. (2019). Overview of modern world experience of established radon action plans. Hygiene of Populated Places: Scientific Journal, No. 69, 154-164.

4. Order of the Cabinet of Ministers of Ukraine dated 27.11.2019 № 1417-r «On approval of the action plan to reduce exposure to radon and its decay products, minimize long-term risks from the spread of radon in residential and non-residential buildings, workplaces for 2020-2024». URL: https://zakon.rada.gov.ua/laws/show/1417-2019p\#Text.

5. IAEA General Safety Requirements No. GSR Part 3. Radiation protection and safety of radiation sources: international basic safety standards. International Atomic Energy Agency. Vienna, 2014, 436 p.

6. IAEA Specific Safety Guide No. SSG-32. Protection of the public against exposure indoors due to radon and other natural sources of radiation. International Atomic Energy Agency. Vienna, 2015, $90 \mathrm{p}$.

7. Council Directive 2013/59/Euratom of 5 December 2013 Laying down basic safety standards for protection against the dangers arising from exposure to ionising radiation, and repealing Directives 89/618/Euratom, 90/641/Euratom, 96/29/Euratom, 97/43/Euratom and 2003/122/Euratom. Official Journal of the European Union. 2014, 57, L13, 73 p.

8. ICRP Publication 55. Optimization and decisionmaking in radiological protection. Annals of the ICRP. 1988, Vol. 20 (1), 60 p.

9. ICRP Publication 126. Radiological protection against radon exposure. Annals of the ICRP. 2014, Vol. 43 (3), 73 p.

10. ICRP Publication 137. Part 3. Occupational intakes of radionuclides. Annals of the ICRP. 2017, Vol. 46 (3-4), 486 p.

11. Pavlenko T. (Project manager). (2019). Scientific justification and developing the main provisions of the Ukrainian radon action plan for protection of the Ukrainian public within implementing Council Directive 2013/59/EURATOM (R\&D report (intermediate)). SI «O. M. Marzieiev Institute for Public Health of the National Academy of Medical Sciences of Ukraine». No. DR 0119 U101022. Kyiv, 85 p. 
12. Law of Ukraine on metrology and metrological activities No. 1314-VII dated 5 June 2014 (as amended) as of 3July 2020 No. 1314-VII, ground No. 2740-VIII. Retrieved from: https://zakon.rada.gov.ua/laws/show/1314-18\#Text.

13. Novikov, V. Author's translation of the international standard ISO/IEC 17025 General requirements for the competence of testing and calibration laboratories. DSTU ISO/IEC 17025:2017. K., 40 p.

14. Friedmann, H. Final results of the Austrian radon project. Health Phys. 2005. Vol. 89, 339-348. doi: 10.1097/01. HP.0000167228.18113.27.

15. Howarth, C., B., Miles, J., C., H. (2007) Results of the 2003 NRPB intercomparison of passive radon detectors. HPA-RPD-027. 63 p. Retrieved from: https://assets.publishing.service.gov. uk/government/uploads/system/uploads/attachment_data/ file/340119/HpaRpd027.pdf.

16. Pantelić, G., Čeliković, I., Živanović, M., Vukanac, I., Nikolić, J., K., Cinelli, G., Gruber, V. (2019). Qualitative overview of indoor radon surveys in Europe. Journal of Environmental Radioactivity. Vol. 204, 163-174. doi: 10.1016/j. jenvrad.2019.04.010.

17. Radiation safety standards of Ukraine (NRBU-97): state health standards. SHS 6.6.1.-6.5.001-98. K., 1998, 135 p.

18. ICRP Publication 115. Lung cancer risk from radon and progeny and statement on radon. Annals of the ICRP. 2010, Vol. 40 (1), 64 p.

19. Population of Ukraine. Population of Ukraine in 2019. Ministry of Finance. Retrieved from: https://index.minfin.com. ua/ua/reference/people/2019/.

20. Gorbulin, V., Kachynskyj, A. (2007). System-conceptual principles of the national security strategy of Ukraine. Kyiv, Euroatlanticinform, $540 \mathrm{p}$.

21. European health for all family of databases. WHO. Retrieved from: http://www.euro.who.int/ru/what-we-do/ data-and-evidence/databases/european-health-for-alldatabase-hfa-db2.

22. Pavlenko, T., German, O., Frizyuk, M., Aksenov, N., Operchyuk, A. (2014). Ukrainian pilot project «Stop Radon». Nuclear Technology \& Radiation Protection. Vol. 29 (2), 142-148. doi: 10.2298/NTRP1402142P.

23. Pavlenko, T., German, O., Aksenov, N., Fryzyuk, M. Operchuk, A. (2018). Radon remediation efficiency assessment in Kirovograd region, Ukraine. Nuclear Technology and Radiation Protection. Vol. XXXIII. No. 3, 317-323. doi: 10.2298/ NTRP1803317P.

\section{Priority Tasks of the Action Plan to Reduce Indoor Radon Levels}

\section{Pavlenko T. ${ }^{1}$, Operchuk A. ${ }^{2}$, Aksenov N. ${ }^{1}$ Fryziuk M. ${ }^{1}$, Myhailenko $0 .{ }^{1}$, Gorval A. ${ }^{1}$}

${ }^{1}$ State Institution «O. M. Marzieiev Institute for Public Health of the National Academy of Medical Sciences of Ukraine», Kyiv, Ukraine ${ }^{2}$ State Institution «Public Health Center of the Ministry of Health of Ukraine», Kyiv, Ukraine

The article provides the justification for the priority steps of radon action plan in Ukraine.

In the first part of the article, the information was analyzed on the geometric mean values of indoor radon activity concentration at the district level of some regions of Ukraine. It was shown that the available data are insufficient for conclusions about the radon-prone areas of almost half of the country. Therefore, an important task is continuing research on indoor radon in unexamined areas. For such studies, it is necessary to ensure consistency of measurement protocols and an appropriate quality assurance system, where interlaboratory comparisons should become a well-established practice for the validation of measurement results. This serves as a basis for the introduction of state databases and the possibility of implementing a single information space on radiation risks.

The article presents a comparative analysis of the existing regulatory framework in Ukraine with international standards. It was established that the current regulatory framework should be revised and improved. Regulatory bodies must determine not only the limit value, but also move to a new unit - radon activity concentration (radon concentration or radon gas level), implement limit values at workplaces which are completely absent today.

The final part of the article substantiates the need to introduce the training system in the field of radon protection and to develop a communication strategy with all potential participants in the implementation of an action plan (public authorities, ministries, regulators, business, media, NGOs and the public, etc.).

It was determined that for the implementation of the state action plan it is necessary to develop recommendations for the organization and approval of regional programs, including methodological recommendations which contain the main areas and tasks depending on the level of the radon hazard of a certain area.

Keywords: indoor radon, radon action plan, reference level, risk communication. 